\title{
WETLAND ECOSYSTEM RESILIENCE: PROTECTING AND RESTORING VALUABLE ECOSYSTEMS
}

\author{
T. L Messer, K. R. Douglas-Mankin, N. G. Nelson, J. R. Etheridge
}

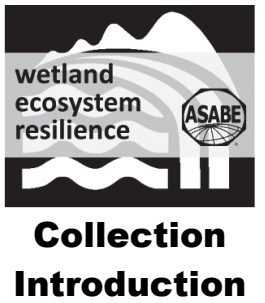

\begin{abstract}
HighLIGHTS
- We provide context and perspectives on articles in the Wetland Ecosystem Resilience collection.

- Insights gained on wetland resilience to sea-level rise and climate change, land use and drainage, and nutrients.
\end{abstract}

\begin{abstract}
The objective of this article is to introduce a collection of articles that explore current research and scientific thought on wetland ecosystem resilience. The collection contains articles on wetland resilience to climate change, agricultural land use-driven change, and recreational land use, along with evaluations of wetland resilience through high-resolution monitoring and modeling tools. Wetland settings in the U.S. span tidal marshes and coastal plain non-riverine wetlands in North Carolina, prairie potholes in Iowa, Appalachian floodplain wetlands, and floating treatment wetlands in the Midwest. The studies in this collection found vertical accretion rates of 0.7 to $4.0 \mathrm{~mm}_{\text {year }}{ }^{-1}$ in a tidal marsh, a wide range of potential wetland hydroperiod responses to climate change, substantial decreases in inundation period, crop yield, and surface-water nitrate (but increases in phosphorus) in artificially drained potholes, and nitrate removal in carbon-amended floating treatment wetlands. Further work is needed to better understand how to design and enhance wetland systems in agricultural regions, better preserve wetland ecosystem services in areas affected by land use and climate change, and provide technical standards for the wide range of designs currently used for wetland treatment systems.
\end{abstract}

Keywords. Agricultural wetlands, Resiliency, Temporal data, Treatment wetlands, Water chemistry, Water quality, Water treatment.

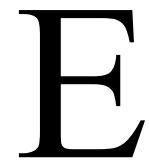
xtreme climate events, alterations in land use practices, and urbanization all impact natural wetland ecosystems. Wetlands provide valuable ecosystem services, but they continue to be threatened worldwide (Hu et al., 2017). Many of the environmental pressures on wetlands have been linked directly to drainage systems that were implemented to convert areas with wetland characteristics (e.g., high water tables, hydric soils, and hydrophytic vegetation) into productive farmland (Dahl, 1998; Zedler and Kercher, 2005). Drained wetland areas have resulted in various ecosystem degradations, including lower water tables in surrounding wetland ecosystems (increasing

Submitted for review in July 2019 as manuscript number NRES 13578; approved for publication as the Introduction to the Wetland Ecosystem Resilience Collection by the Natural Resources \& Environmental Systems Community of ASABE in August 2019.

The authors are Tiffany L. Messer, Assistant Professor and Water Quality Scientist, Daugherty Water for Food Global Institute Faculty Fellow, Department of Biological Systems Engineering, University of Nebraska, Lincoln, Nebraska; Kyle Douglas-Mankin, Research Leader, USDA-ARS Water Management and Systems Research Unit, Fort Collins, Colorado; Natalie Nelson, Assistant Professor, Department of Biological and Agricultural Engineering, North Carolina State University, Raleigh, North Carolina; James Randall Etheridge, Assistant Professor, Department of Engineering, East Carolina University, Greenville, North Carolina. Corresponding author: Tiffany Messer, 217 L.W. Chass Hall, University of Nebraska, Lincoln, NE 68583-0726; phone: 402-472-2232; e-mail: tiffany.messer@unl.edu. the potential for peat fires), reduction of flood abatement, saltwater intrusion, and increased nutrient pollution in waterways downstream of converted wetlands. These impacts have led to a cascade of other ecological consequences (e.g., acidification, harmful algae blooms, hypoxia, contamination of drinking water aquifers, and loss of biodiversity) (Bhattachan et al., 2018; Carnicer et al., 2015; Chescheir et al., 1991; Matson et al., 1997; Ribaudo et al., 2011).

Wetlands provide a wide range of ecosystem services, which include but are not limited to habitat provision, water quality improvement, recreation, carbon sequestration, property value increase, and water storage (Aiona et al., 2018). However, these ecosystem services have been degraded due to pressures from climate change, including sea level rise (Aumen et al., 2014; Kirwan and Gedan, 2019), alterations in land use and water level fluctuations benefiting invasive species (Anteau, 2012), and disruptions of wetland food webs due to emerging contaminants flowing from urbanized and agricultural regions (Marshall et al., 2016). Therefore, a better understanding of the impact of changing climate, land practices, and urbanization on these ecosystems is critical for understanding their resilience to diverse stressors.

This article introduces the Wetland Ecosystem Resilience Special Collection, which was sponsored by the Ecological Engineering committee (NRES-28) and the Streams, Reservoirs, and Wetlands Group (NRES-25) of ASABE. This Special Collection comprises six peer-reviewed articles that 
focus on wetland ecosystem resilience across diverse landscapes and wetland types and expands on a recent series of articles on wetlands and coastal systems in Transactions of the ASABE (Agouridis et al., 2016). This introduction provides context for the collection and perspective on these articles, which focus on wetland resilience to climate change and land use, and presents new methods for wetland ecosystem monitoring. In this collection, we define wetland resilience as the ability to maintain critical ecosystem services over a range of disturbances, such as extreme climate events, alterations in land use practices, and urbanization. Summaries of the articles and their relevance to these themes are provided below.

\section{Wetland Resilience to Climate Change}

Kamrath et al. (2019) evaluated vertical accretion in a created tidal marsh in North Carolina. The objective of their study was to evaluate the surface elevation changes and underlying processes of a young created brackish tidal marsh using deep rod surface elevation tables (RSET) and feldspar marker horizons $(\mathrm{MH})$. Vertical elevations increased by 0.7 to $4.0 \mathrm{~mm}$ year $^{-1}$, which supports vertical accretion in created marshes as comparable to vertical accretion in natural marshes. The findings from this study are important first steps for assessing the resilience and hydrologic planning in coastal regions to reduce the impacts of sea level rise. Further, recommendations are provided for designers to accommodate sufficient elevation capital in created marshes to allow marsh establishment.

Kurki-Fox et al. (2019) used the modeling software DRAINMOD (Skaggs et al., 2012) to estimate the potential effects of changes in temperature and precipitation on wetland hydroperiods. DRAINMOD was calibrated and validated for two largely undisturbed wetlands in coastal North Carolina. Nine climate models were selected to represent a range of possible climate change scenarios. The results indicated that the effects of climate change on wetland hydroperiods in this region may be minimal if the mean temperature change is less than $1.5^{\circ} \mathrm{C}$ and if there is no decrease in precipitation. However, the more extreme scenarios show that the mean water table could drop by as much as $84 \mathrm{~cm}$. The simulation results indicate that future changes in temperature and precipitation have potential to produce substantial changes in water table levels in non-riverine wetlands of the North Carolina coastal plain. Potential consequences from these alterations include one of the wetland sites no longer being considered a jurisdictional wetland and alteration to the wetland ecology for both sites. This study exemplifies the need for active management of water levels in the future if these ecosystems are to be sustained in their present form.

\section{WeTland RESILIENCE TO Agricultural LAND USE-DRIVEN CHANGE}

Martin et al. (2019a) investigated the hydrologic resilience of farmed pothole depressions and hydroperiod effects on crop yields in Iowa over two years. The objectives of their study were to compare inundation area and depth of eight prairie potholes and evaluate the water balance with varying levels of drainage. Inundation patterns were monitored hourly during the growing season to assess wetland hydrology and impacts on corn and soybean yields. The study reported that the addition of surface inlet drainage decreased the period of inundation following a rain event. However, the resilience of these wetlands to meet jurisdictional wetland hydrologic criteria remained persistent even with the addition of drainage structures.

In a complementary but distinct study, Martin et al. (2019b) analyzed two years of daily water quality and depth data from eight prairie potholes to evaluate how the resilience of pothole hydrology and treatment capacity varied across seasonal and event scales. Due to their locations on farmlands, the potholes received nutrient-rich agricultural runoff. The study results show that pothole nutrient loads increased early in the growing season when fertilizer was applied and ground cover was absent, and that nitrate reduction occurred in the potholes during $85 \%$ of the multi-day events observed during the two-year study period.

\section{WetLand Resilience to Water QUaLity Pressures THROUGH DeSIGN}

Few studies have investigated the impact of floating treatment wetlands for recreational lakes in agricultural regions, specifically to enhance water quality in both urban and agricultural regions. Keilhauer et al. (2019) evaluated the resilience of floating treatment wetland design for water quality improvements. Nitrate-N removal rates were quantified for traditional and carbon-amended (spent coffee grounds) floating treatment wetland mesocosms in the Midwestern U.S. using two vegetation designs. Nitrate-N removal rates increased throughout the growing season and following the addition of spent coffee grounds. Further, spent coffee grounds in mesocosms without floating treatment wetlands were found to have similar nitrate-N removal rates to mesocosms with only spent coffee ground amendments. The findings from the study provide new insight on the impacts of growing season, plant species, and carbon amendments on nitrate-N removal performance of floating treatment wetlands during the establishment year in a Midwestern setting.

\section{Evaluating Wetland Resilience With High- RESOLUTION MONITORING AND MODELING}

Jensen and Ford (2019) present a novel integration of high-resolution water quality data with a hydrological and biogeochemical process model. The model was used to examine the nitrate export from a disturbed forested watershed in southwestern West Virginia and the retention of nitrate by a confluence wetland. Unlike other disturbed forested watersheds where much of the nitrate export occurs at baseflow, $65 \%$ of nitrate export in the studied watershed occurred during the highest $2 \%$ of flows. The wetland at the confluence of the studied stream (Fourpole Creek) and the Ohio River had estimated nitrate removal of $2.6 \%$ to $58.5 \%$ annually. The Ohio River served as a secondary source to the confluence wetland during backwater conditions. The model confirmed that higher residence times resulting from inundation of the confluence floodplain wetland increased nitrate removal. This study, which is one of the first to use high-resolution water quality data to evaluate a model, shows the po- 
tential of high-resolution monitoring data for reducing uncertainty in model results.

\section{Conclusions}

The studies in this Special Collection advance the scientific understanding of the resilience of wetlands as natural and built ecosystems. The collection investigates the current state of high-resolution wetland sensing and modeling, wetland resilience to sea level rise and climate change, land use impact on wetlands from subsurface drainage, and nutrient changes in natural and built wetland systems. Further work is needed to better understand how to design and enhance wetland systems in agricultural regions, better preserve wetland ecosystem services in areas affected by land use and climate change, and provide technical standards for the wide range of designs currently used for wetland treatment systems.

\section{REFERENCES}

Agouridis, C. T., Douglas-Mankin, K. R., Linhoss, A. C., \& Mittelstet, A. R. (2016). Wetlands and coastal systems: Protecting and restoring valuable ecosystems. Trans. ASABE, 59(5), 1299-1301. https://doi.org/10.13031/trans.59.12103

Aiona, P. K., Luek, J. L., Timko, S. A., Powers, L. C., Gonsior, M., \& Nizkorodov, S. A. (2018). Effect of photolysis on absorption and fluorescence spectra of light-absorbing secondary organic aerosols. ACS Earth Space Chem., 2(3), 235-245. https://doi.org/10.1021/acsearthspacechem.7b00153

Anteau, M. J. (2012). Do interactions of land use and climate affect productivity of waterbirds and prairie-pothole wetlands? Wetlands, 32(1), 1-9. https://doi.org/10.1007/s13157-011-02063

Aumen, N. G., Havens, K. E., Best, G. R., \& Berry, L. (2014). Predicting ecological responses of the Florida Everglades to possible future climate scenarios: Introduction. Environ. Mgmt., 55(4), 741-748. https://doi.org/10.1007/s00267-014-0439-z

Bhattachan, A., R.E. Emanuel, M. Ardon, E.S. Bernhardt, S.M. Anderson, et al. 2018. Evaluating the effects of land-use change and future climate change on vulnerability of coastal landscapes to saltwater intrusion. Elem Sci Anth 6(1): 62. doi: 10.1525/elementa.316.

Carnicer, J., Sardans, J., Stefanescu, C., Ubach, A., Bartrons, M., Asensio, D., \& Penuelas, J. (2015). Global biodiversity, stoichiometry, and ecosystem function responses to humaninduced C-N-P imbalances. J. Plant Physiol., 172, 82-91. https://doi.org/10.1016/j.jplph.2014.07.022

Chescheir, G. M., Skaggs, R. W., Gilliam, J. W., \& Broadhead, R. G. (1991). Hydrology of two forested wetlands that receive pumped agricultural drainage water in eastern North Carolina. Wetlands, 11(1), 29-54. https://doi.org/10.1007/BF03160839

Dahl, T. E. (1998). Monitoring wetland changes: The U.S. wetlands status and trends study. Falls Church, VA: U.S. Fish and Wildlife Service. Retrieved from https://www.fws.gov/wetlands/Documents/Monitoring-
Wetland-Changes-The-US-Wetlands-Status-and-TrendsStudy.pdf

Hu, S., Niu, Z., Chen, Y., Li, L., \& Zhang, H. (2017). Global wetlands: Potential distribution, wetland loss, and status. Sci. Total Environ., 586, 319-327. https://doi.org/10.1016/j.scitotenv.2017.02.001

Jensen, A. K., \& Ford, W. I. (2019). Quantifying nitrate dynamics of a confluence floodplain wetland in a disturbed Appalachian watershed: High-resolution sensing and modeling. Trans. ASABE, 62(6), (in press). https://doi.org/10.13031/trans.13278

Kamrath, B. J. W., Burchell, M. R., Cormier, N., Krauss, K. W., \& Johnson, D. J. (2019). The potential resiliency of a created tidal marsh to sea level rise. Trans. ASABE, 62(6), (in press). https://doi.org/10.13031/trans.13438

Keilhauer, M. G., Messer, T. L., Mittelstet, A. R., Franti, T. G., \& Corman, J. R. (2019). Nitrate removal by floating treatment wetlands amended with spent coffee: A mesocosm scale evaluation. Trans. ASABE, 62(6), (in press). https://doi.org/10.13031/trans.13431

Kirwan, M. L., \& Gedan, K. B. (2019). Sea-level driven land conversion and the formation of ghost forests. Nature Clim. Change, 9(6), 450-457. https://doi.org/10.1038/s41558-0190488-7

Kurki-Fox, J. J., Burchell II, M. R., \& Kamrath, B. J. (2019). The potential long-term impacts of climate change on the hydrologic regimes of North Carolina's coastal plain non-riverine wetlands. Trans. ASABE, 62(6), (in press). https://doi.org/10.13031/trans.13437

Marshall, S., Sharley, D., Jeppe, K., Sharp, S., Rose, G., \& Pettigrove, V. (2016). Potentially toxic concentrations of synthetic pyrethroids associated with low-density residential land use. Front. Environ. Sci., 4, article 75. https://doi.org/10.3389/fenvs.2016.00075

Martin, A. R., Kaleita, A. L., \& Soupir, M. L. (2019a). Inundation patterns of farmed pothole depressions with varying subsurface drainage. Trans. ASABE, 62(6), (in press). https://doi.org/10.13031/trans.13435

Martin, A. R., Soupir, M. L., \& Kaleita, A. L. (2019b). Seasonal and intra-event nutrient levels in farmed prairie potholes of the Des Moines Lobe. Trans. ASABE, 62(6), (in press). https://doi.org/10.13031/trans.13414

Matson, P. A., Parton, W. J., Power, A. G., \& Swift, M. J. (1997). Agricultural intensification and ecosystem properties. Science, 277(5325), 504-509. https://doi.org/10.1126/science.277.5325.504

Ribaudo, M., Delgado, J., Hansen, L., Livingston, M., Mosheim, R., \& Williamson, J. (2011). Nitrogen in agricultural systems: Implications for conservation policy. USDA-ERS Economic Research Report No. 127. Washington, DC: USDA Economic Research Service. https://doi.org/10.2139/ssrn.2115532

Skaggs, R. W., Youssef, M. A., \& Chescheir, G. M. (2012). DRAINMOD: Model use, calibration, and validation. Trans. ASABE, 55(4), 1509-1522. https://doi.org/10.13031/2013.42259

Zedler, J. B., \& Kercher, S. (2005). Wetland resources: Status, trends, ecosystem services, and restorability. Ann. Rev. Environ. Resour., 30(1), 39-74. https://doi.org/10.1146/annurev.energy.30.050504.144248 